\title{
Using Traditional Medicinal Plants from Arid and Desert Rangelands as a Potential Treatment for Covid-19 in Southern Tunisia
}

\section{Mouldi Gamoun}

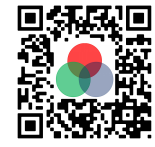

Use your smartphone to scan this QR code and download this article

International Center for Agricultural Research in the Dry Areas (ICARDA), 2049 Ariana, Tunisia

Email:M.Gamoun@cgiar.org

History

- Received: Sep 06, 2021

- Accepted: Sep 10, 2021

- Published: Oct 01, 2021

DOI : 10.15419/ajhs.v7i2.491

\section{Check for updates}

\section{Copyright}

(c) Biomedpress. This is an openaccess article distributed under the terms of the Creative Commons Attribution 4.0 International license.

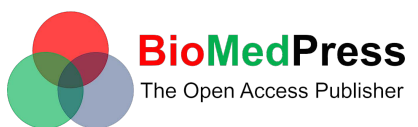

\begin{abstract}
Rangelands provide good services, including forage for livestock, aromatic and medicinal plants, wildlife habitat, fuel wood, and the watershed. In the arid and desert rangelands of Tunisia, several medicinal plants are used locally in traditional medicine. Many of them have been scientifically investigated and validated. This study aimed to document the different plants used recently to treat and prevent Covid-19 by the rural communities in southern Tunisia. One hundred persons that were ensured to be cured after their infection by Covid-19 were asked to indicate what plants were used to prevent or treat the pandemic disease. It is noteworthy that the selected respondents did not use any other medication than medicinal plants due to the high price of medicament. Additionally, they had not received any Covid-19 vaccinations to date. Five species were harvested from the range lands to be used by the rural population in south Tunisia to treat and prevent Covid19. The plants included Rosmarinus officinalis, Thymbra capitata, Peganum harmala, Artemisia herbaalba and Astragalus armatus. These species are medicinally essential when it comes to treating several human diseases. Still, there are no new scientific findings on whether these conclusions are valid. These results can still be the subject of future scientific research.

Key words: folk medicine, coronavirus, cure, global pandemic
\end{abstract}

\section{INTRODUCTION}

Native range lands are an important source of rare and environmentally, economically, nutritionally, and medically valued plants around the globe. In recent decades, increased attention has been paid to the potential of wild plants in terms of medicinal uses. In many regions of the world, most medicinal plants grow in natural range lands rather than being planted ${ }^{1}$. In China, for example, it is estimated that $80 \%$ of medicinal plants are provided by the natural resources ${ }^{2,3}$. In addition, it is estimated that $80 \%$ of the world population uses herbal medicine as part of its primary health care, with about $12 \%$ being from South Asia ${ }^{4}$. Given the importance of plants in medicine, the Sri Lankan Government established the Ministry of Indigenous Medicine in 1980 due to the high demand for the drugs based on plants ${ }^{5}$.

The arid environment is also one of diversity in terms of medicinal herbs and it is home to a large number of unique species ${ }^{6}$. Despite being under threat from various biotic and abiotic stresses, many arid range lands still produce medicinal plants that are valued in both traditional and modern medicine. Their harvesting greatly contributes to the annual livelihood income of many populations ${ }^{7-9}$. The excessive and unsustainable collection of medicinal plants on a large scale from the range lands contributes to rangeland degradation and the extinction of some plant species ${ }^{10}$.

Tunisia's rangelands occupy about 5.5 million ha, of which $87 \%$ of them are arid ${ }^{11}$. These lands form the largest part of the Tataouine governorate surface, making up about $27 \%$ of the total rangeland in Tunisia ${ }^{12}$. Despite these harsh environments, arid rangelands are blessed with a wide diversity of medicinal plants due to their diverse ecological habitats ${ }^{13-15}$. An ethnobotanical survey conducted of a local community in Tataouine reported that 70 plant species are used for therapeutic purposes ${ }^{16}$. Through the floristic surveys conducted by Gamoun and Louhaichi ${ }^{12}$, a total of 279 species were recorded in the rangelands of Tataouine, and 35 of them were found to be greatly used in both traditional and modern medicine.

Given the spread of diseases, medicinal plants are gaining attention in the context of traditional use. Recently, more than 199 million infections with at least 4 million Covid-19 associated deaths were reported by July $2021^{17}$.

Tunisia is among the countries most severely affected by the ongoing pandemic, with more than 560 thou- 
sand infections and at least 18 thousand deaths reported by July $2021^{17}$. In light of the Covid-19 pandemic, the fragile health care system, and the lack of infrastructure, the use of medicinal plants has acquired a renewed interest by the rural population of Tunisia. The present study has therefore attempted to reveal some of the medicinal plants used in the south of Tunisia to prevent or treat Covid-19 infection.

\section{METHODOLOGY}

Tataouine is located in the south of Tunisia, totaling 150 thousand inhabitants. It recorded close to 10,500 coronavirus cases and 410 deaths by the end of July $2021^{18}$. Due to this record of infection, the slow pace of vaccination in Tunisia, and the mistrust in the available Covid-19 vaccines held by some people, the community has become increasingly disappointed. This has led them to using native plants which may help them to address the current pandemic. In July 2021, 100 persons that were cured of Covid-19 were asked to indicate what plants were used to prevent or treat the disease. It is noteworthy that the selected respondents did not use any medication other than the medicinal plants due to the high price of medication and that they had not received any Covid-19 vaccinations to date.

\section{RESULTS AND DISCUSSION}

Botanical studies conducted in the arid and desert rangeland of Tataouine have identified a rich collection of over 270 plants from 58 families ${ }^{11,12}$, where $65 \%$ of the family contributions are from Asteraceae, Poaceae, Fabaceae, Amaranthaceae, Brassicaceae, Boraginaceae, Caryophyllaceae, Lamiaceae, Apiaceae, and Cistaceae. The rangeland is botanically endowed with rich and diverse medicinal plants where 35 plant species belonging to 15 families are greatly used in both traditional and modern medicine. Lamiaceae and Apiaceae were found to occur in the highest proportion for medicinal use. The families with the highest number of species were Lamiaceae with 6 species, Apiaceae with 4, Amaryllidaceae Amaranthaceae, Asteraceae, Brassicaceae, Amaryllidaceae, Ephedraceae, Fabaceae, Nitrariaceae, Poaceae, Polygonaceae, Ephedraceae, Fabaceae, Nitrariaceae, Poaceae, Polygonaceae with 2 species each, and Apocynaceae, Capparaceae, Caryophyllaceae, Cucurbitaceae, Rhamnaceae, Thymelaeaceae, Zygophyllaceae with a single species each.
Five species were harvested from the rangelands and used by the local community to treat and prevent Covid-19 (Table 1). These included Rosmarinus officinalis, Thymbra capitata, Peganum harmala, Artemisia herba-alba and Astragalus armatus.

The most important species in terms of the number of users was R. officinalis, used by 47 people. In addition, T. capitata was used by 25 people, followed by $P$. harmala by 19 people, $A$. herba-alba by 16 and $A$. armatus by 12 people. Some of the respondents used pairs of species at a time. Of the 100 interviewed, 12 people used $R$. officinalis and T. capitata, 5 people used $P$. harmala and A. herba-alba and 2 people used A. armatus and A. herba alba.

Rosmarinus officinalis L.is a perennial shrub native to the Mediterranean basin belonging to Lamiaceae family (Figure 1). It is more commonly known as rosemary and "Iklil" in classical Arabic. It has multiple uses including medicinal, aromatic, and ornamental ${ }^{19}$. R. officinalis as an essential oil has important inflammatory ${ }^{20-23}$, antimutagenic ${ }^{24,25}$, cytotoxic $^{26-28}$, antiphlogistic ${ }^{24,29}$, analgesic ${ }^{30-32}$, antiobesity $^{33}$ and hepatoprotective applications ${ }^{34,35}$, as well as being used in the prevention and treatment of diabetic and cardiovascular diseases ${ }^{36}$. It is also well known for its biological active essential oils that are antioxidants ${ }^{37-39}$, anticancer ${ }^{28,40,41}$, antibacterial $^{42,43}$, and antifungal ${ }^{44-46}$. Moreover, R. officinalis is a pulmonary antiseptic, as well as stomachic, hypertensive, and antidiarrheal due to its diuretic and sudorific qualities ${ }^{15}$.

The leaves of $R$. officinalis were the most used plant part by the local people in the treatment of Covid-19. They boiled the dried rosemary leaves in water and drank it once it had cooled.

Thymbra capitata (L.) Cav., is a perennial herbaceous shrub native to the Mediterranean area, belonging to Lamiaceae family (Figure 2). It is commonly known as thyme and it is locally known as "Zaâtar horr". In southern Tunisia, it is represented by scattered populations on sandy and often rocky soils. T. capitata is known for the effectiveness of its essential oil as part of a local utilization for traditional medicinal purposes. It is widely used for folk medicinal purposes to treat arterial hypertension, ulcers, colic, digestive and respiratory system disorders, and diarrhea ${ }^{47,48}$. Nowadays, the essential oil of T. capitata is gaining interest due its potential biological properties ${ }^{49,50}$. It is mainly known for being an antioxidant ${ }^{51}$, anti-inflammatory ${ }^{52,53}$,

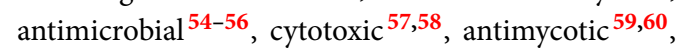
anticancer $^{61}$, antiproliferative ${ }^{62}$, and antifungal ${ }^{63}$. These main biological activities were reported to be 
Table 1: Traditional medicinal plants used by local population in the south of Tunisia against Covid-19

\begin{tabular}{|c|c|c|c|}
\hline Plant species & Common name & Part used & Indication \\
\hline R. officinalis & Rosemary & Leaves & $\begin{array}{l}\text { Boiling dried leaves of rosemary in water and drank } \\
\text { when it cools. }\end{array}$ \\
\hline T. capitata & Conehead thyme & Leaves & $\begin{array}{l}\text { Boiling dried leaves of } T \text {. capitata in water and drank } \\
\text { when it cools. } \\
\text { To treat coughs, fever, and bronchitis, leaf powder is } \\
\text { mixed with honey and applied to the chest. }\end{array}$ \\
\hline P. harmala & Wild rue & $\begin{array}{l}\text { Stems, leaves } \\
\text { and seeds }\end{array}$ & $\begin{array}{l}\text { Wild rue smoke efficacy against Covid-19: putting } \\
\text { leaves, seeds, stems, on hot coals, and breathe the } \\
\text { smoke through the nose, and it will cause all rheum to } \\
\text { go away. } \\
\text { Fumigate the home to prevent the spread of all kinds of } \\
\text { infectious diseases. }\end{array}$ \\
\hline A. herba-alba & $\begin{array}{l}\text { White worm- } \\
\text { wood }\end{array}$ & Leaves & $\begin{array}{l}\text { Putting the leaves of } A \text {. herba-alba on hot coals, and } \\
\text { breathes the smoke through the nose, and it will cause } \\
\text { all rheum to go away. }\end{array}$ \\
\hline A. armatus & Milkvetch & Roots & $\begin{array}{l}\text { Decoction of roots of } A \text {. armatus is orally taken to treat } \\
\text { and prevent Covid-19, because it can stimulate the im- } \\
\text { mune system and act against viruses like the ones that } \\
\text { cause colds. }\end{array}$ \\
\hline
\end{tabular}

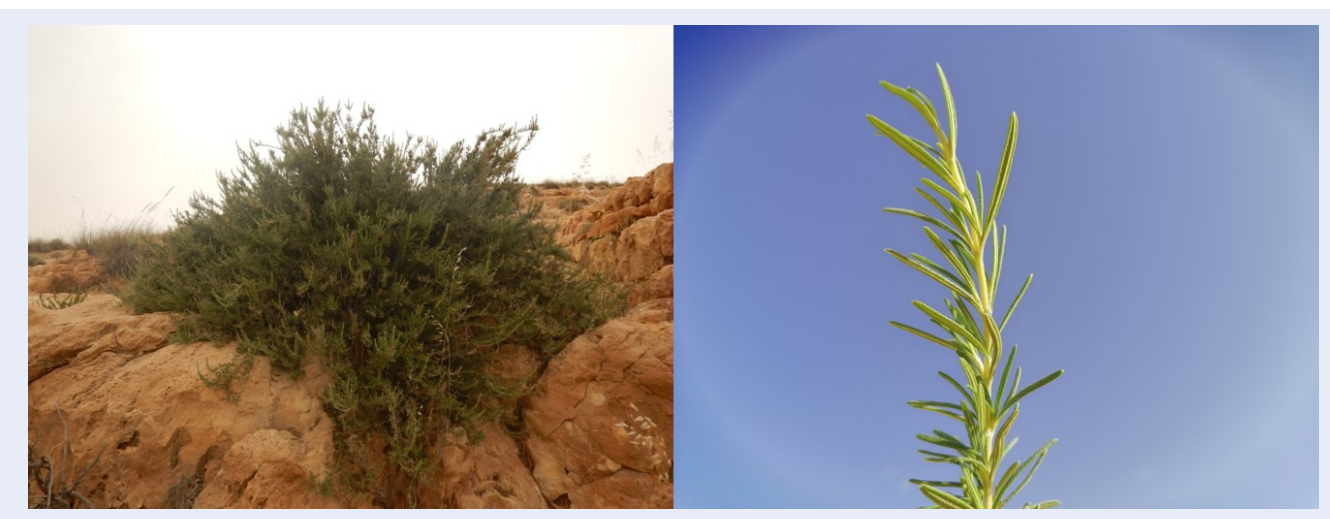

Figure 1: Rosmarinus officinalis L.

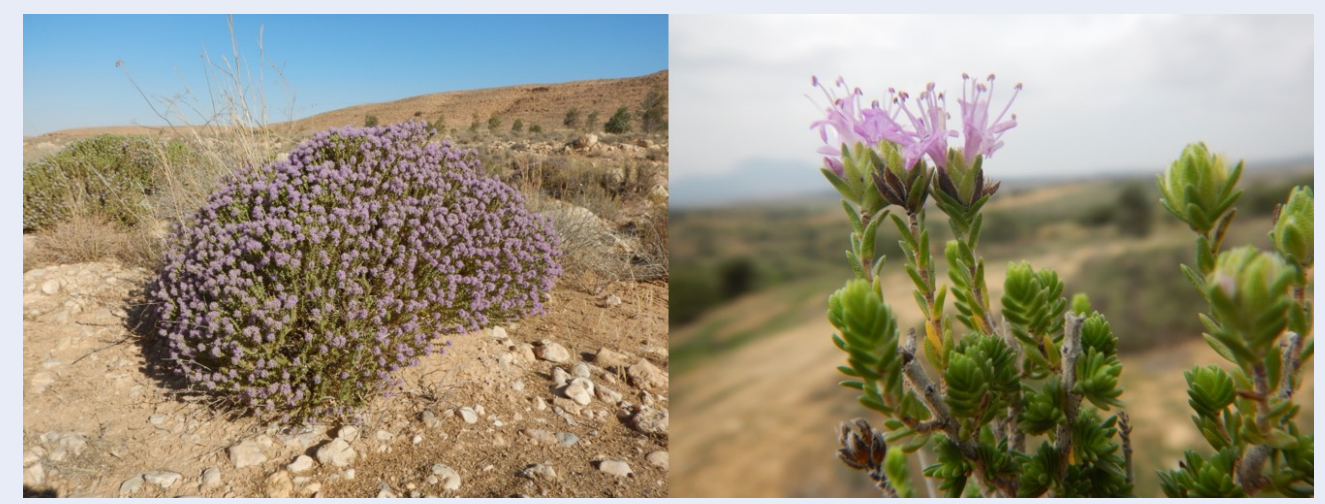

Figure 2: Thymbra capitata (L.) Cav. 


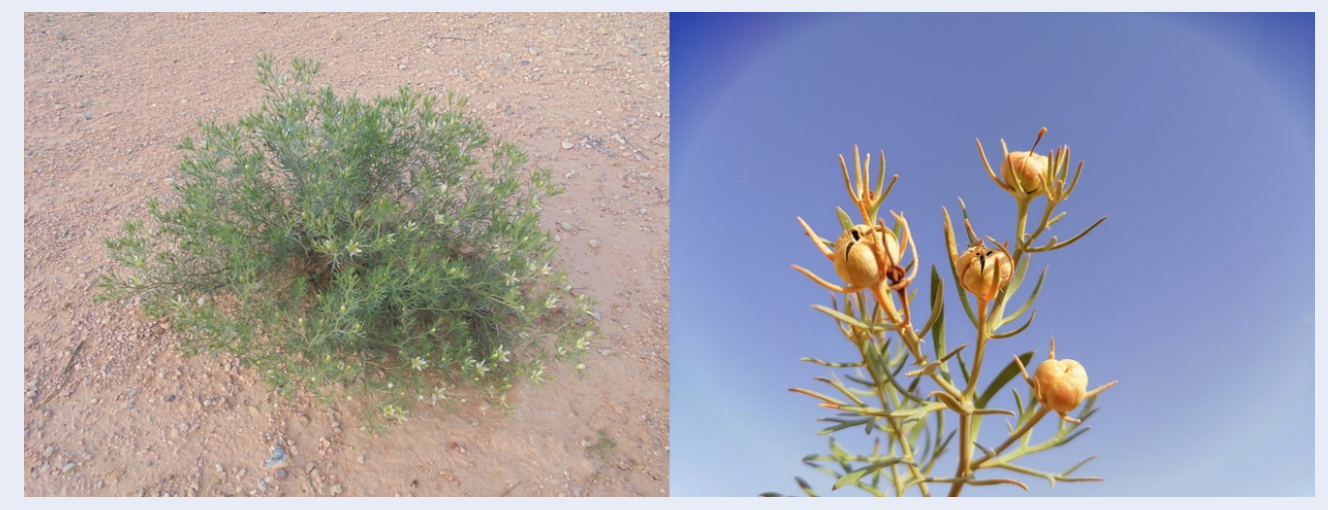

Figure 3: Peganum harmala L.

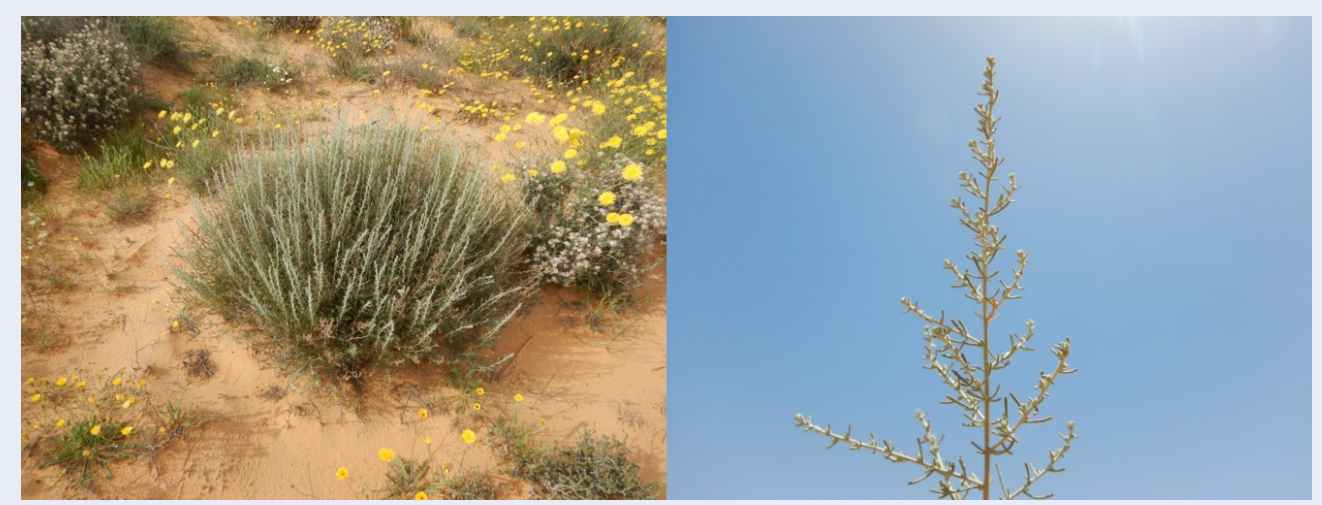

Figure 4: Artemisia herba-alba Asso.

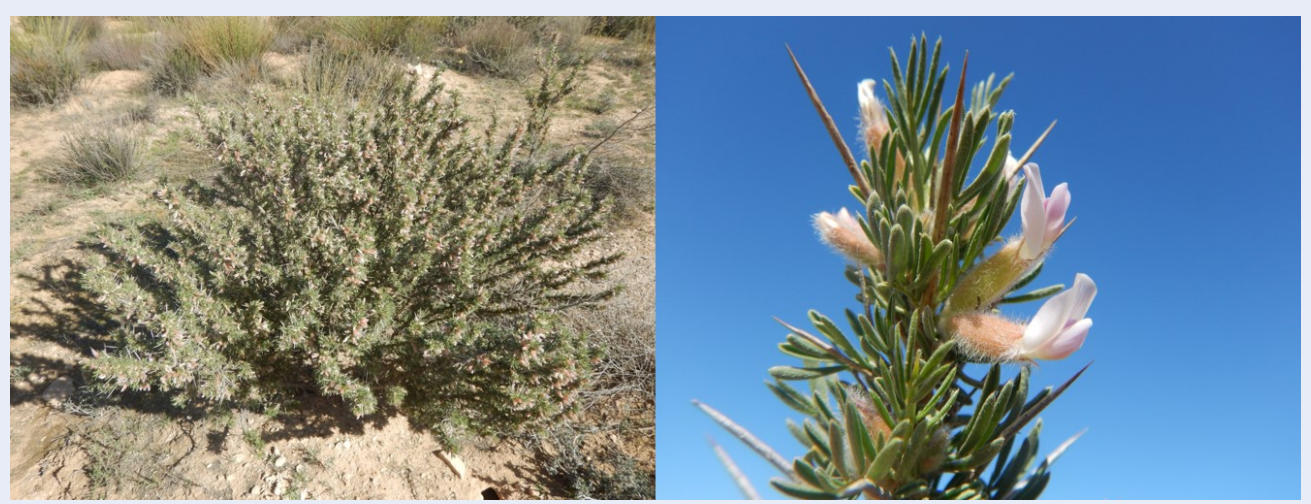

Figure 5: Astragalus armatus Willd. 
due to its richness of phenolic compounds in the extracted essential oils ${ }^{64-66}$.

The leaves of Thymbra capitata were found to be the plant part used the most by the local people in their treatment of Covid-19. They boiled the dried leaves of T. capitata in water and drank the mixture when it cooled. Likewise, the leaf powder was also mixed with honey and applied to the chest to treat coughs, a fever, and bronchitis.

Peganum harmala L. is a herbaceous perennial flowering plant that is widely distributed in Central Asia, North Africa, and the Middle East (Figure 3). It is commonly known as African rue, Syrian rue, and wild rue. This plant, known as harmal in North Africa, belongs to the Nitrariaceae family. Peganum harmala is a noxious invasive species. It is toxic to livestock when fresh but medicinally important ${ }^{67}$. The seeds are known to possess hypothermic properties ${ }^{68,69}$ and it is effective in the treatment of dermatosis $^{70}$. Furthermore, P. harmala was shown to possess lactogogue, antihelmitic, antispasmodic, abortifient, antipyretic, emetic, emmenagogue, cardiovascular, neurologic, antimicrobial, gastrointestinal, anticancer, and antidiabetic activities ${ }^{71}$. It has also been found that $P$. harmala has insecticidal and anti-tumor effects ${ }^{72}$, as well as being antileishmanial $^{73}$, anti-spasmodic, anti-malaria ${ }^{72}$, vasorelaxant and anti-histaminic ${ }^{74}$. This is as well as promoting wound healing, antioxidant activity, immunomodulator properties, and leukemia healing ${ }^{75}$ with analgesic and anti-inflammatory properties. Finally, it also has antinociceptive ${ }^{76}$, hepatoprotective ${ }^{77}$, hypoglycemic, antitumor ${ }^{78}$, cytotoxic, antifungal, antibacterial and antiviral effects ${ }^{79}$.

To treat and prevent Covid-19, the local community takes any part of $P$. harmala (leaves, seeds, stems, roots) and puts it on hot coals. They breathe in the smoke through the nose. This causes all of the rheum to go away.

Artemisia herba-alba Asso., is a perennial shrub belonging to the Asteraceae family. It is commonly known as white wormwood and it is locally known as "Chih." (Figure 4). It is widespread in the arid and semi-arid steppes of North Africa, Southwestern Europe, and the Middle East. Since ancient times, A. herba-alba has been extensively used in traditional medicine to treat hypertension, scorpion/snake bites, diabetes, colds, parasitic infections, intestinal disturbances, bronchitis, diarrhea, neuralgias, stomach pains, and hemorrhoids ${ }^{16,80-83}$. It is known for its antioxidant, anticancer, antimicrobial, anti-inflammatory, genotoxic, cytotoxic, antiacetylcholinesterase, and fungicidal activities ${ }^{84-88}$.
To treat and prevent Covid-19, the local community takes the leaves of $A$. herba-alba and puts them on hot coals. They breathe in the smoke through the nose, and this causes all of the rheum to go away.

Astragalus armatus Willd. is a perennial spiny shrub native to Algeria, Libya, Morocco, and Tunisia. It is commonly known as thorny milkvetch and it is locally known as "Guetet" (Figure 5). Astragalus armatus has been used in traditional medicine as an effective treatment for leishmaniasis and helminthiasis ${ }^{89}$. It also relieves odentonecrosis ${ }^{16}$. Nowadays, pods of Astragalus armatus are receiving interest due to their potential antioxidant, anticholinesterase, antibacterial and phagocytic activities ${ }^{90}$. They are also a source of the bioactive galactomannan ${ }^{91}$. The genus Astragalus (Astragalus membranaceus; Astragalus mongholicus) is used to prevent colds and upper respiratory infections, to protect and support the immune system, to protect the liver, to decrease blood pressure, and to cure diabetes ${ }^{92,93}$ ).

A water decoction of roots of A. armatus is orally taken to treat and prevent Covid-19 because it can stimulate the immune system, helping it to fight against viruses like the ones that cause colds.

Fear used to grip the country. This seemed clear before the vaccine became available sufficiently. The intensification of the fourth wave of coronavirus has killed thousands of people. In this changing epidemiological situation, people have resorted to looking to plants to boost their immunity. Among the most used species, there are those that have been mentioned above such as $R$. officinalis, T. capitata, P. harmala, A. herba-alba, and A. armatus. Some native species have been traditionally valued for warding off winter flu, which shares some symptoms with the new coronavirus.

Recent studies have shown that $R$. officinalis and $T$. capitata have been used by Tunisian and Moroccan Covid-19 patients due to their antiviral properties and the presence of various complex chemical substances that may play an important role in the inhibition of Covid-1994,95. R. officinalis has a potential role, due to its natural antiviral compounds, in the development of plant-based drugs to use against coronavirus ${ }^{96,97}$. In vitro evidence shows that a mixture of essential oils from three Cretan Aromatic Plants (Thymbra capitata (L.) Cav., Salvia fruticosa Mill. and Origanum dictamnus L.) inhibits SASR-CoV-2 proliferation. This may be a valuable addition for the prevention and/or treatment of mild Covid-1998. The positive effects of $P$. harmala against several viruses have been proven through in vitro experiments including SARS-CoV-2 and influenza virus, both of 
which have indications similar to Covid-19. This means that it is likely to be effective in the treatment of Covid-1999,100. Asdadi et al. ${ }^{101}$ and Attah et al. ${ }^{102}$ suggested that $A$. herba-alba has possible potential against Covid-19 due to its antiviral activities. A. armatus is used to treat several human diseases but there is no good scientific evidence to support its efficacy against Covid-19, although it may have some antiviral activity. Some Astragalus species, such as Astragalus membranaceus, have been used in traditional Chinese Medicine in the treatment of Covid-19 ${ }^{103}$.

From these results, supported by other research findings and databases, we suggest that these species have potential against Covid-19 but more scientific research is required to validate their validity.

\section{CONCLUSION}

Today, the world faces an ongoing Covid-19 pandemic. This pandemic has become a significant challenge when it comes to human security. Tunisia, like every country in the world, is facing the Covid-19 pandemic and the many connected challenges that it has caused. Due to the increased price of the cost of medication and medical supplies and the projected increase in the incidence of Covid-19, the use of medicinal plants has grown rapidly among rural populations. The arid and desert range lands of Tunisia provide a habitat for several medicinal plants used in traditional medicine that are used to prevent and treat Covid-19 such as Rosmarinus officinalis, Thymbra capitata, Peganum harmala, Artemisia herba-alba, and Astragalus armatus. However, harvesting shrubs for fuel wood and overgrazing is threatening the flora biodiversity found in these range lands and the lives of the people who live there. This calls for urgent action.

\section{ABBREVIATIONS}

None.

\section{ACKNOWLEDGMENTS}

The author would like to thank all the participants who entirely voluntarily participated in this study for providing their detailed and thoughtful responses.

\section{AUTHOR'S CONTRIBUTIONS}

None

\section{FUNDING}

None

\section{AVAILABILITY OF DATA AND MATERIALS}

Data and materials used and/or analyzed during the current study are available from the corresponding author on reasonable request.

\section{ETHICS APPROVAL AND CONSENT TO PARTICIPATE}

Not applicable.

\section{CONSENT FOR PUBLICATION}

Not applicable.

\section{COMPETING INTERESTS}

The authors declare that they have no competing interests.

\section{REFERENCES}

1. Cole NH. Diversity of Medicinal Plants in West African Habitats. In: van der Maesen LJG, van der Burgt XM, van Medenbach de Roy JM, editors. 14th \{AETFAT\} \{C\}ongress. Wageningen, The Netherlands: Kluwer Academic Publishers; 1996. p. 704-713. Available from: 10.1007/978-94-009-0285-5_86.

2. Xiao PG. The Chinese approach to medicinal plants their utilization and conservation. Cambridge: Cambridge University Press; 1991.

3. He SA, Sheng H. 1997. Utilization and conservation of medicinal plants in China with special reference to Atractylodes lancea. In: FAO. (1997). Medicinal Plants for Forest Conservation and Healthcare. FAO, Rome, Italy.

4. Woo JM, Cho SH. Traditional Korean medicine practitioners' attitudes toward evidence based medicine: a qualitative study. Eur J Integr Med. 2012;4(4):e448-54. Available from: 10.1016/j.eujim.2012.09.004.

5. FAO. Use and potential of wild plants in farm households. Rome, Italy; 1999.

6. Gintzburger G, Toderich K, Mardonov B, Mahmudov M. Rangelands of the Arid and Semi-Arid zones in Uzbekistan. CIRAD-ICARDA.; 2003.

7. Hasan MK, Gatto P, Jha PK. Can environmental income from wild medicinal plants contributes to annual household income: a case study from Makawanpur district in Nepal. International Journal of Medicinal and Aromatic. 2013;3:18-26.

8. Rasul G, Choudhary D, Pandit BH, Kollmair M. Poverty and livelihood impacts of a medicinal and aromatic plants project in India and Nepal: an assessment. Mt Res Dev. 2012;32(2):137-48. Available from: 10.1659/MRDJOURNAL-D-11-00112.1.

9. Sher H, Aldosari A, Ali A, de Boer HJ. Economic benefits of high value medicinal plants to Pakistani communities: an analysis of current practice and potential. J Ethnobiol Ethnomed. 2014;10(1):71. PMID: 25304516. Available from: 10.1186/1746-4269-10-71.

10. IUCN. 2006. Conserving Medicinal Species. Securing a Healthy Future. Miththapala S. (ed) IUCN: Ecosystems and Livelihoods Group, Asia.

11. Gamoun M, Belgacem AO, Louhaichi M. Diversity of desert rangelands of Tunisia. Plant Divers. 2018;40(5):217-25. PMID: 30740567. Available from: 10.1016/j.pld.2018.06.004.

12. Gamoun M, Louhaichi M. Botanical Composition and Species Diversity of Arid and Desert Rangelands in Tataouine, Tunisia. Land (Basel). 2021;10(3):313. Available from: 10 . 3390/land10030313.

13. Floc'h EL. Contribution à une Étude Ethnobotanique de la Flore Tunisienne. Tunis, Tunisia: Imprimerie Officielle de la République Tunisienne; 1983. 
14. You H, Jin H, Khaldi A, Kwak M, Lee T, Khaine I. Plant Diversity in Different Bioclimatic Zones in Tunisia. J Asia-Pac Biodivers. 2016;9(1):56-62. Available from: 10.1016/j.japb.2016.01.002.

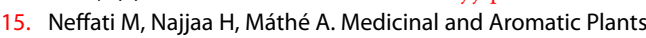
of the World-Africa; Springer Nature: Berin/Heidelberg, Germany, Volume 3.; 2017.

16. Karous O, Jilani IBH, Ghrabi-Gammar Z. Ethnobotanical Study on Plant Used by Semi-Nomad Descendants' Community in Ouled Dabbeb-Southern Tunisia. Plants. 2021;10(4):642. PMID: 33800664. Available from: 10.3390/ plants 10040642.

17. World Health Organisation (2021). Timeline: WHO's COVID 19 response. Available at: https://www.who.int/emergencie s/diseases/novel-coronavirus-2011/interactive-timeline (Accessed Jul 25, 2021).; 2021.

18. Ministry of Public Health 2021.

19. Louhaichi M, Gamoun M. Rosmarinus officinalis: a multipurpose species; a medicinal, aromatic, and ornamental plant. Managing rangelands: promoting pastoral species that are more popular and widely effective medicinal values; 2020.

20. Altinier G, Sosa S, Aquino RP, Mencherini T, Loggia RD, Tubaro A. Characterization of topical antiinflammatory compounds in Rosmarinus officinalis L. J Agric Food Chem. 2007;55(5):1718-23. PMID: 17288440. Available from: 10. $1021 /$ jf062610+.

21. Poeckel D, Greiner C, Verhoff M, Rau O, Tausch L, Hörnig C. Carnosic acid and carnosol potently inhibit human 5lipoxygenase and suppress pro-inflammatory responses of stimulated human polymorphonuclear leukocytes. Biochem Pharmacol. 2008;76(1):91-7. PMID: 18508031. Available from: 10.1016/j.bcp.2008.04.013.

22. Lai CS, Lee JH, Ho CT, Liu CB, Wang JM, Wang YJ. Rosmanol potently inhibits lipopolysaccharide-induced $\mathrm{NOS}$ and COX2 expression through downregulating MAPK, NF-kappaB, STAT3 and C/EBP signaling pathways. J Agric Food Chem. 2009;57(22):10990-8. PMID: 19856917. Available from: 10. 1021/jf9025713.

23. Benincá JP, Dalmarco JB, Pizzolatti MG, Fröde TS. Analysis of the anti-inflammatory properties of Rosmarinus officinalis $L$. in mice. Food Chem. 2011;124(2):468-75. Available from: 10.1016/j.foodchem.2010.06.056

24. Oluwatuyi M, Kaatz GW, Gibbons S. Antibacterial and resistance modifying activity of Rosmarinus officinalis. Phytochemistry. 2004;65(24):3249-54. PMID: 15561190. Available from: 10.1016/j.phytochem.2004.10.009.

25. Marzouk Z, Neffati A, Marzouk B, Charaief I, Fathia K, Ghedira LC. Chemical composition and antibacterial and antimutagenic activity of Tunisian Rosmarinus officinalis L. oil from Kasserine. J Food Agric Environ. 2006;4:61-5.

26. Hussain Al, Anwar F, Chatha SA, Jabbar A, Mahboob S, Nigam PS. Rosmarinus officinalis essential oil: antiproliferative, antioxidant and antibacterial activities. Braz J Microbiol. 2010;41(4):1070-8. PMID: 24031588. Available from: 10. 1590/S1517-83822010000400027.

27. Zuhairi JJA, Kashi FJ, Rahimi-Moghaddam A, Yazdani M. Antioxidant, cytotoxic and antibacterial activity of Rosmarinus officinalis L. essential oil against bacteria isolated from urinary tract infection. Eur J Integr Med. 2020;38:101-92. Available from: 10.1016/j.eujim.2020.101192.

28. Jardak M, Elloumi-Mseddi J, Aifa S, Mnif S. Chemical composition, anti-biofilm activity and potential cytotoxic effect on cancer cells of Rosmarinus officinalis L. essential oil from Tunisia. Lipids Health Dis. 2017;16(1):190. PMID: 28969677. Available from: 10.1186/s12944-017-0580-9.

29. Okoh OO, Sadimenko AP, Afolayan AJ. Comparative evaluation of the antibacterial activities of the essential oils of Rosmarinus officinalis L. obtained by hydrodistillation and solvent free microwave extraction methods. Food Chem. 2010;120(1):308-12. Available from: 10.1016/j.foodchem. 2009.09.084.
30. Takaki I, Bersani-Amado LE, Vendruscolo A, Sartoretto SM, Diniz SP, Bersani-Amado CA. Anti-inflammatory and antinociceptive effects of Rosmarinus officinalis L. essential oil in experimental animal models. J Med Food. 2008;11(4):741-6. PMID: 19053868. Available from: 10.1089/jmf.2007.0524.

31. Martínez AL, González-Trujano ME, Chávez M, Pellicer F. Antinociceptive effectiveness of triterpenes from rosemary in visceral nociception. J Ethnopharmacol. 2012;142(1):2834. PMID: 22543174. Available from: 10.1016/j.jep.2012.03. 052.

32. Lucarini R, Bernardes WA, Ferreira DS, Tozatti MG, Furtado R, Bastos JK. In vivo analgesic and anti-inflammatory activities of Rosmarinus officinalis aqueous extracts, rosmarinic acid and its acetyl ester derivative. Pharm Biol. 2013;51(9):108790. PMID: 23738822. Available from: 10.3109/13880209.2013. 776613.

33. Sedighi R, Zhao Y, Yerke A, Sang S. Preventive and protective properties of rosemary (Rosmarinus officinalis L.) in obesity and diabetes mellitus of metabolic disorders: a brief review. Curr Opin Food Sci. 2015;2:58-70. Available from: 10.1016/j. cofs.2015.02.002.

34. Rašković A, Milanović I, Pavlović N, Cébović T, Vukmirović S, Mikov M. Antioxidant activity of rosemary (Rosmarinus officinalis L.) essential oil and its hepatoprotective potential. BMC Complement Altern Med. 2014;14(14):225. PMID: 25002023. Available from: 10.1186/1472-6882-14-225.

35. Ramadan KS, Khalil OA, Danial EN, Alnahdi HS, Ayaz NO. Hypoglycemic and hepatoprotective activity of Rosmarinus officinalis extract in diabetic rats. J Physiol Biochem. 2013;69(4):779-83. PMID: 23625639. Available from: 10 . 1007/s13105-013-0253-8.

36. Hsieh $\mathrm{CL}$, Peng $\mathrm{CH}$, Chyau $\mathrm{CC}$, Lin $\mathrm{YC}$, Wang $\mathrm{HE}$, Peng RY. Low-density lipoprotein, collagen, and thrombin models reveal that Rosemarinus officinalis L. exhibits potent antiglycative effects. J Agric Food Chem. 2007;55(8):2884-91. PMID: 17385882. Available from: 10.1021/jf0631833.

37. Beretta G, Artali R, Facino RM, Gelmini F. An analytical and theoretical approach for the profiling of the antioxidant activity of essential oils: the case of Rosmarinus officinalis L. J Pharm Biomed Anal. 2011;55(5):1255-64. PMID: 21511423. Available from: 10.1016/j.jpba.2011.03.026.

38. Hendel N, Larous L, Belbey L. Antioxidant activity of rosemary (Rosmarinus offcinalis L.) and its in vitro inhibitory effect on Penicillium digitatum. Int Food Res J. 2016;23:172532.

39. Takayama C, Faria FM, Almeida AC, Dunder RJ, Manzo LP, Socca EA. Chemical composition of Rosmarinus officinalis essential oil and antioxidant action against gastric damage induced by absolute ethanol in the rat. Asian Pac J Trop Biomed. 2016;6(8):677-81. Available from: 10.1016/j.apjtb. 2015.09.027.

40. Degner SC, Papoutsis AJ, Romagnolo DF. Watson RR, editor. Health benefits of traditional culinary and medicinal Mediterranean plants. New York: E-Publishing Inc.; 2009. Available from: 10.1016/B978-0-12-374228-5.00026-3.

41. Gezici S, Sekeroglu N, Kijjoa A. In vitro anticancer activity and antioxidant properties of essential oils from populus alba $L$. and Rosmarinus officinalis L. from South Eastern Anatolia of Turkey. Indian Journal of Pharmaceutical Education and Research. 2017;51:498-503. Available from: 10.5530/ijper.51.3s. 74.

42. Jarrar N, Abu-Hijleh A, Adwan K. Antibacterial activity of Rosmarinus officinalis $L$. alone and in combination with cefuroxime against methicillin-resistant Staphylococcus aureus. Asian Pac J Trop Med. 2010;3(2):121-3. Available from: 10.1016/S1995-7645(10)60049-1.

43. Bernardes WA, Lucarini R, Tozatti MG, Flauzino LG, Souza MG, Turatti IC. Antibacterial activity of the essential oil from Rosmarinus officinalis and its major components against oral pathogens. Z Naturforsch C J Biosci. 2010;65(9-10):588-93. PMID: 21138060. Available from: 10.1515/znc-2010-9-1009. 
44. Bozin B, Mimica-Dukic N, Samojlik I, Jovin E. Antimicrobial and antioxidant properties of rosemary and sage (Rosmarinus officinalis $\mathrm{L}$. and Salvia officinalis L., Lamiaceae) essential oils. J Agric Food Chem. 2007;55(19):7879-85. PMID: 17708648. Available from: 10.1021/jf0715323.

45. Özcan MM, Chalchat JC. Chemical composition and antifungal activity of rosemary (Rosmarinus officinalis L.) oil from Turkey. Int J Food Sci Nutr. 2008;59(7-8):691-8. PMID: 18654909. Available from: 10.1080/09637480701777944.

46. Rasooli I, Fakoor MH, Yadegarinia D, Gachkar L, Allameh A, Rezaei MB. Antimycotoxigenic characteristics of Rosmarinus officinalis and Trachyspermum copticum L. essential oils. Int J Food Microbiol. 2008;122(1-2):135-9. PMID: 18190993. Available from: 10.1016/j.ijfoodmicro.2007.11.048.

47. Bouraoui $O$. La médecine traditionnelle dans le gouvernorat de Sousse. Thèse de Médecine. Faculté de médecine de Sousse, Tunisie.; 2000.

48. Stahl-Biskup E, Sáez F. Thyme, the Genus Thymus. London: Taylor and Francis; 2002.

49. Ali IBEH, Guetat A, Boussaid M. A combined approach using allozymes and volatiles for the characterization of Tunisian Thymbra capitata (L.) Cav. (Lamiaceae). Ind Crops Prod. 2013;43:477-83. Available from: 10.1016/j.indcrop.2012.07. 059.

50. Neves A, Marto J, Duarte A, Gonçalves LM, Pinto P, Figueiredo $A C$, et al.. Characterization of Portuguese Thymbra capitata, Thymus caespititius and Myrtus communis essential oils in topical formulations. Flavour Frag. J. 32 : 392-402. .

51. Aazza S, El-Guendouz S, Miguel MG, Antunes MD, Faleiro ML, Correia Al. Antioxidant, Anti-inflammatory and Anti-hyperglycaemic Activities of Essential Oils from Thymbra capitata, Thymus albicans, Thymus caespititius, Thymus carnosus, Thymus lotocephalus and Thymus mastichina from Portugal. Nat Prod Commun. 2016;11(7):1029-38. PMID: 30452188. Available from: $10.1177 / 1934578 X 1601100739$

52. Carrasco A, Perez E, Cutillas AB, Martinez-Gutierrez R, Tomas $V$, Tudela J. Origanum vulgare and Thymbra capitata Essential Oils from Spain: Determination of Aromatic Profile and Bioactivities. Nat Prod Commun. 2016;11(1):113-20. PMID: 26996035. Available from: 10.1177/1934578X1601100133.

53. Albano SM, Miguel MG. Biological activities of extracts of plants grown in Portugal. Ind Crops Prod. 2011;33(2):33843. Available from: 10.1016/j.indcrop.2010.11.012.

54. de Oliveira AP, de Oliveira RP, Gaspar A, Salgueiro L, Cavaleiro C, de Oliveira JM. Association of Thymbra capitata essential oil and chitosan (TCCH hydrogel): a putative therapeutic tool for the treatment of vulvovaginal candidosis. Flavour Fragrance J. 2013;28(6):354-9. Available from: 10.1002/ffj.3144.

55. Faleiro L, Miguel G, Gomes S, Costa L, Venâncio F, Teixeira A. Antibacterial and antioxidant activities of essential oils isolated from Thymbra capitata L. (Cav.) andOriganum vulgare L. J Agric Food Chem. 2005;53(21):8162-8. PMID: 16218659. Available from: 10.1021/jf0510079.

56. Merino N, Berdejo D, Bento R, Salman H, Lanz M, Maggi F. Antimicrobial efficacy of Thymbra capitata (L.) Cav. essential oil loaded in self-assembled zein nanoparticles in combination with heat. Ind Crops Prod. 2019;133:98-104. Available from: 10.1016/j.indcrop.2019.03.003.

57. Dć AM, Nikolić BJ, Giweli AA, Mitić-Culafić DS, Soković MD, Ristić MS. Libyan Thymus capitatus essential oil: antioxidant, antimicrobial, cytotoxic and colon pathogen adhesioninhibition properties. J Appl Microbiol. 2015;119(2):389-99. PMID: 26033505. Available from: 10.1111/jam.12864.

58. Elmi A, Ventrella D, Barone F, Benvenuti S, Scozzoli M, Bacci ML. Preliminary evaluations of the effects of Cuminum cyminum and Coriandrum sativum essential oils on swine spermatozoa. JSM Sex Med. 2017;2:1012.

59. Sacchetti G, Maietti S, Muzzoli M, Scaglianti M, Manfredini S, Radice M. Comparative evaluation of 11 essential oils of different origin as functional antioxidants, antibacterials and antimicrobials in foods. Food Chem. 2005;91(4):621-32.
Available from: 10.1016/j.foodchem.2004.06.031.

60. Bounatirou S, Smiti S, Miguel MG, Faleiro L, Rejeb MN, Neffati M. Chemical composition, antioxidant and antibacterial activities of the essential oils isolated from Tunisian Thymus capitatus Hoff. et Link. Food Chem. 2007;105(1):146-55. Available from: 10.1016/j.foodchem.2007.03.059.

61. Delgado-Adámez J, Garrido M, Bote ME, Fuentes-Pérez MC, Espino J, Martín-Vertedor D. Chemical composition and bioactivity of essential oils from flower and fruit of Thymbra capitata and Thymus species. J Food Sci Technol. 2017;54(7):1857-65. PMID: 28720941. Available from: 10 . 1007/s13197-017-2617-5.

62. Miguel MG, Gago C, Antunes MD, Megías C, Cortés-Giraldo I, Vioque J. Antioxidant and antiproliferative activities of the essential oils from Thymbra capitata and Thymus species grown in Portugal. Evid Based Complement Alternat Med. 2015;2015:851721. PMID: 26229547. Available from: 10 . $1155 / 2015 / 851721$.

63. Salgueiro LR, Pinto E, Gonçalves MJ, Pina-Vaz C, Cavaleiro $C$, Rodrigues AG. Chemical composition and antifungal activity of the essential oil of Thymbra capitata. Planta Med. 2004;70(6):572-5. PMID: 15229809. Available from: 10.1055/ s-2004-827162.

64. Ali IB, Guetat A, Boussaid M. Variation of volatiles in Tunisian populations of Thymbra capitata (L.) Cav. (Lamiaceae). Chem Biodivers. 2012;9(7):1272-85. PMID: 22782875. Available from: $10.1002 / \mathrm{cbdv} .201100344$.

65. Jaouadi R, Cardoso SM, Silva AM, Yahia IBH, Boussaid M, Zaouali Y. Variation of phenolic constituents of Tunisian Thymus capitatus (L.) Hoff. et Link. populations. Biochem Syst Ecol. 2018;77:10-5. Available from: 10.1016/j.bse.2017.12. 009.

66. Moukhles A, Belcadi H, Raissouni I, Driss AB, Mansour Al. Chemical Composition, in vitro Antibacterial Activity and Corrosion Inhibition of Essential Oil and Hydrolat Extract from Aerial Parts of Thymbra capitata (L.) Cav Harvested at Northern Morocco. Journal of Essential Oil Bearing Plants. 2020;23(2):375-389. Available from: 10.1080/0972060X. 2020.1760147 .

67. Gamoun M, Louhaichi M. Peganum harmala L.: noxious invasive species, toxic to livestock but medicinally important. Managing agrosilvopastoral systems: controlling invasive perennial species; 2021. Available from: https://hdl.handle. net/20.500.11766/12437.

68. Kuhn MA, Winston D. Herbal therapy and supplements, a scientific and traditional approach. New York: Lippincott; 2000.

69. Yuruktumen A, Karaduman S, Bengi F, Fowler J. Syrian rue tea: a recipe for disaster. Clin Toxicol (Phila). 2008;46(8):749-52. PMID: 18803088. Available from: 10 . 1080/15563650701323205.

70. El-Rifaie MES, Rifaie M. Peganum harmala: its use in certain dermatoses. Int J Dermatol. 1980;19(4):221-2. PMID: 7399797. Available from: 10.1111/j.1365-4362.1980.tb00305. $\mathrm{x}$.

71. Mina CN, Farzaei MH, Gholamreza A. Medicinal properties of Peganum harmala L. in traditional Iranian medicine and modern phytotherapy: a review. J Tradit Chin Med. 2015;35(1):104-9. PMID: 25842736. Available from: 10.1016/ S0254-6272(15)30016-9.

72. Goel N, Singh N, Saini R. Efficient in vitro multiplication of Syrian Rue (Peganum harmala L.) using 6-benzylaminopurine pre-conditioned seedling explants. Nat Sci. 2009;7:129-34.

73. Mirzaie M, Nosratabadi SJ, Derakhshanfar AA, Sharifi I. Antileishmanial activity of Peganum harmala extract on the in vitro growth of Leishmania major promastigotes in comparison to a trivalent antimony drug. Vet Arh. 2007;77(4):365-75.

74. Asghari G, Lockwood GB. Stereo specific biotransformation of phenylethyl propionate by cell cultures of Peganum harmala L. Iran Biomed J. 2002;6:43-6.

75. Zaker F, Oody A, Arjmand A. A study on the antitumoral and differentiation effects of peganum harmala derivatives 
in combination with ATRA on leukaemic cells. Arch Pharm Res. 2007;30(7):844-9. PMID: 17703736. Available from: $10.1007 / \mathrm{BF} 02978835$

76. Monsef HR, Ghobadi A, Iranshahi M, Abdollahi M. Antinociceptive effects of Peganum harmala L. alkaloid extract on mouse formalin test. J Pharm Pharm Sci. 2004;7(1):65-9. PMID: 15144736.

77. Hamden K, Masmoudi H, Ellouz F, ElFeki A, Carreau S. Protective effects of Peganum harmala extracts on thioureainduced diseases in adult male rat. J Environ Biol. 2008;29(1):73-7. PMID: 18831335

78. Sobhani AM, Ebrahimi SA, Mahmoudian M. An in vitro evaluation of human DNA topoisomerase I inhibition by Peganum harmala L. seeds extract and its beta-carboline alkaloids. J Pharm Pharm Sci. 2002;5(1):19-23. PMID: 12042115.

79. Darabpour E, Bavi AP, Motamedi H, Nejad SMS. Antibacterial activity of different parts of Peganum harmala L. growing in Iran against multi-drug resistant bacteria. EXCLI J. 2011;10:252-63. PMID: 29033706.

80. Boukef MK. Les plantes dans la médecine traditionnelle en Tunisie. In: Médecine traditionnelle et pharmacopée. Edits., Agence de Coopération culturelle et Technique, pp. 95-96, Paris, France.

81. Tahraoui A, El-Hilaly J, Israili ZH, Lyoussi B. Ethnopharmacological survey of plants used in the traditional treatment of hypertension and diabetes in south-eastern Morocco (Errachidia province). J Ethnopharmacol. 2007;110(1):105-17. PMID: 17052873. Available from: 10.1016/j.jep.2006.09.011.

82. Salido S, Valenzuela LR, Altarejos J, Nogueras M, Sanchez A, Cano E. Composition and infraspecific variability of Artemisia herba-alba from southern Spain. Biochem Syst Ecol. 2004;32(3):265-77. Available from: 10.1016/j.bse.2003. 09.002 .

83. Mohamed AE, El-Sayed MA, Hegazy ME, Helaly SE, Esmail AM, Mohamed NS. Chemical Constituents and Biological Activities of Artemisia Herba Alba. Rec Nat Prod. 2010;4:1-25.

84. Khlifi D, Sghaier RM, Amouri S, Laouini D, Hamdi M, Bouajila J. Composition and anti-oxidant, anti-cancer and anti-inflammatory activities of Artemisia herba-alba, Ruta chalpensis L. and Peganum harmala L. Food Chem Toxicol. 2013;55:202-8. PMID: 23333573. Available from: 10.1016/j. fct.2013.01.004.

85. Mighri $\mathrm{H}$, Hajlaoui $\mathrm{H}$, Akrout A, Najjaa N, Neffati M. Antimicrobial and antioxidant activities of Artemisia herba-alba essential oil cultivated in Tunisian arid zone. C R Chim. 2010;13(3):380-6. Available from: 10.1016/j.crci.2009.09.008

86. Abderrahman SM, Shbailat SJ. Genotoxic and cytotoxic effects of Artemisia herba-alba on mammalian cells. Caryologia: International Journal of Cytology. Cytosystematics and Cytogenetics. 2014;67:265-72.

87. Saleh MA, Belal MH, el Baroty G. Fungicidal activity of Artemisia herba alba Asso (Asteraceae). J Environ Sci Health B. 2006;41(3):237-44. PMID: 16484084. Available from: $10.1080 / 03601230500354774$

88. Younsi F, Trimech R, Boulila A, Ezzine O, Dhahri S, Boussaid M. Essential Oil and Phenolic Compounds of Artemisia herba-alba (Asso.): Composition, Antioxidant, Antiacetylcholinesterase, and Antibacterial Activities. Int J Food Prop. 2016;19(7):1425-38. Available from: 10.1080/10942912.2015. 1079789.

89. Chermat S, Gharzouli R. Ethnobotanical study of medicinal flora in the North East of Algeria-An empirical knowledge in Djebel Zdimm (Setif). J Mar Sci Eng. 2015;5:50-9.

90. Labed A, Ferhat M, Labed-Zouad I, Kaplaner E, Zerizer S, Voutquenne-Nazabadioko L. Compounds from the pods of Astragalus armatus with antioxidant, anticholinesterase antibacterial and phagocytic activities. Pharm Biol. 2016;54(12):3026-32. PMID: 27431425. Available from 10.1080/13880209.2016.1200632.

91. Boual Z, Pierre G, Delattre C, Benaoun F, Petit E, Gardarin C. Mediterranean semi-arid plant Astragalus armatus as a source of bioactive galactomannan. Bioact Carbohydr Diet Fibre. 2015;5(1):10-8. Available from: 10.1016/j.bcdf.2014.11. 002 .

92. Zhang HW, Lin ZX, Xu C, Leung C, Chan LS. Astragalus (a traditional Chinese medicine) for treating chronic kidney disease. Cochrane Database Syst Rev. 2014;10(10). PMID: 25335553. Available from: 10.1002/14651858.CD008369.pub2.

93. Shao BM, Xu W, Dai H, Tu P, Li Z, Gao XM. A study on the immune receptors for polysaccharides from the roots of Astragalus membranaceus, a Chinese medicinal herb. Biochem Biophys Res Commun. 2004;320(4):1103-11. PMID: 15249203. Available from: 10.1016/j.bbrc.2004.06.065.

94. Wannes WA, Tounsi MS. Can medicinal plants contribute to the cure of Tunisian COVID-19 patients? Journal of Medicinal Plants Studies. 2020;8(5):218-26. Available from: 10.22271/ plants.2020.v8.i5c.1218.

95. Alami AE, Fattah A, Chait A. Medicinal Plants Used for the Prevention Purposes during the Covid-19 Pandemic in Morocco. J Anal Sci Appl Biotech. 2020;2(1):4-11.

96. Sytar $O$, Brestic $M$, Hajihashemi $S$, Skalicky $M$, Kubeš J, Lamilla-Tamayo L. COVID-19 Prophylaxis Efforts Based on Natural Antiviral Plant Extracts and Their Compounds. Molecules. 2021;26(3):727. PMID: 33573318. Available from: 10.3390/molecules26030727.

97. Silva EF, Silva PF, Rico TM. Anti-Sars-CoV effect of Rosemary (Rosmarinus officinalis): A blind docking strategy. MOL2NET, International Conference Series on Multidisciplinary Sciences CHEMINFOUNC-02: Chemoinformatics Workshop, UNC Chape Hill, USA.

98. Lionis C, Karakasiliotis I, Petelos E, Linardakis M, Diamantakis A, Symvoulakis E, et al.. A mixture of essential oils from three Cretan Aromatic Plants (thyme, Greek sage and Cretan dittany, (APeo) inhibits SASR-CoV-2 proliferation: in vitro evidence and a Proof-of-Concept intervention study in mild ambulatory COVID-19-positive patients. medRxiv.; 2021.01.11.20248947.

99. Tuzun B, Nasibova T, Garaev E, Sayin K, Ataseven H. Could Peganum harmala be effective in the treatment of COVID19? BratisI Lek Listy. 2021;122(9):670-9. PMID: 34463115.

100. Moradi MT, Karimi A, Rafieian-Kopaei M, Fotouhi F. In vitro antiviral effects of Peganum harmala seed extract and its total alkaloids against Influenza virus. Microb Pathog. 2017;110:42-9. PMID: 28629724. Available from: 10.1016/ j.micpath.2017.06.014.

101. Asdadi A, Hamdouch A, Gharby S, Hassani LAl. Chemical characterization of essential oil of Artemisia herba-alba asso and his possible potential against covid-19. J Analyt Sci Appl Biotechnology. 2020;2(2):67-72.

102. Attah AF, Fagbemi AA, Olubiyi O. Therapeutic potentials of ant-iviral plants used in traditional African medicine with COVID-19 infocus: a Nigerian perspective. Front Pharmacol. 2021;12:1-29.

103. Luo H, Tang QL, Shang $Y X$, Liang SB, Yang M, Robinson $N$, et al. Can Chinese Medicine Be Used for Prevention of Corona Virus Disease 2019 (COVID-19)? A Review of Historical Classics, Research Evidence and Current Prevention Programs Chin J Integr Med. 2020;26(4):243-250. Available from: 10.1007/s11655-020-3192-6. 
Ready to submit your manuscript? Choose Biomedpress and benefit from:

- Fast, convenient online submission

- Through peer-review by experienced researchers

- Rapid publication on acceptance

- Free of charge (without publication fees)

Learn more http://www.biomedpress.org/journals/

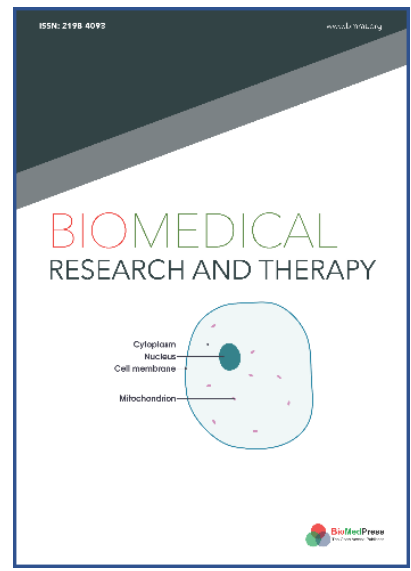

\title{
Biomedical Research and Therapy
}

Indexed: Web of Science (ESCl), Embase, Google Scholar

Journal Citation Indicator (2020): 0.16

Acceptance Rate (2020): 54.32\%

Article Publishing Charge: Free

Submission to first editorial decision: 27 days

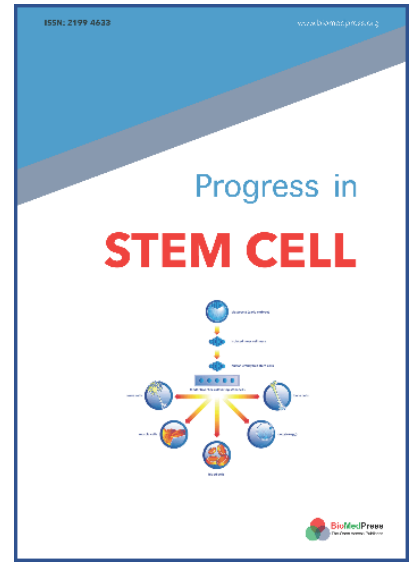

\section{Progress in Stem Cell}

Indexed: Embase, Google Scholar

Acceptance Rate (2020): 78.19\%

Article Publishing Charge: Free

Submission to first editorial decision: 19 days

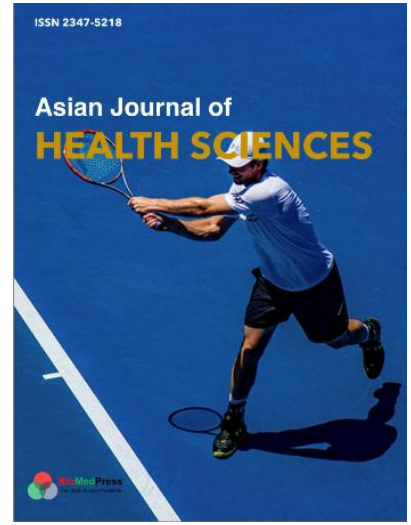

\author{
Asian Journal of Health Sciences \\ Indexed: Google Scholar \\ Acceptance Rate (2020): 72.89\% \\ Article Publishing Charge: Free \\ Submission to first editorial decision: 16.5 days
}

